\section{Vertikální distribuce radioaktivního cezia-137 v půdě}

\section{EVA JURANOVÁ, JOSEF KRATINA, BARBORA SEDLÁŘOVÁ, DIANA MAREŠOVÁ, MICHAL NOVÁK, IRENA POHLOVÁ, JOSEF VOJTĚCH DATEL}

Klíčová slova: radioaktivita - cezium-137 - půda - kontaminace vertikální distribuce - zranitelnost podzemních vod

\section{SOUHRN}

Životní prostředí České republiky bylo $v$ minulosti kontaminováno umělými radionuklidy $v$ důsledku spadu po testech jaderných zbraní a z havárie v Černobylu. Článek shrnuje výsledky sledování vertikální migrace ${ }^{137} \mathrm{Cs}$ v půdě ve vybraných lokalitách, které je prováděno jako součást sběru dat pro hodnocení zranitelnosti podzemních vod. Do sledování byly zahrnuty tři lokality různých typů krajinného pokryvu (les, louka a orná půda). Pro zjištění migrace umělých radionuklidů v půdním profilu byly odebírány vzorky do hloubky $100 \mathrm{~cm}$, jež byly poté analyzovány pomocí spektrometrie záření gama. Dále byly stanoveny některé půdní vlastnosti (zrnitost, obsah humusu). Z výsledků plyne, že stále měřitelná je kontaminace pưd radionuklidem ${ }^{137} \mathrm{Cs}$. Nejvyšší aktivity ${ }^{137} \mathrm{Cs}$ se ve třech sledovaných lokalitách pohybovaly v rozmezí $21,0 \mathrm{~Bq} \cdot \mathrm{kg}^{-1}$ až 32,2 Bq $\mathrm{kg}^{-1}$. Tato maxima byla ve všech třech sledovaných lokalitách naměřena ve svrchních vrstvách půd $($ do $10 \mathrm{~cm})$. Ve vertikálním profilu tedy ${ }^{137} \mathrm{Cs}$ migruje jen velmi pomalu; je převážně na půdu pevně vázáno. V menší míře ovšem dochází v čase i k transportu kontaminace směrem k hlubším vrstvám půdy. U dvou lokalit je hloubka, v níž byla detekována měritelná aktivita ${ }^{137} \mathrm{Cs}$, odhadována na $30 \mathrm{~cm}$, resp. $35 \mathrm{~cm}$. Ve třetí lokalitě to bylo dokonce $80 \mathrm{~cm}$. Zde ale existuje podezření i na jiné vlivy, které mohly transport ${ }^{137} \mathrm{Cs}$ ovlivnit. Z hlediska zranitelnosti podzemních vod se zdá, že proti pronikání ${ }^{137} \mathrm{Cs}$ jsou poměrně dobře ochráněny. Toto zjištění bude ještě ověřeno analýzou podzemních vod a zahrnutím dalších informací v následující etapě prací.

\section{ÚVOD}

Umělé radionuklidy vznikají v důsledku lidských aktivit a v životním prostredí se, až na výjimky, přirozeně nevyskytují. Mohou však do něj být vneseny lidskou činností [1]. Největším zdrojem kontaminace severní hemisféry umělými radionuklidy byly atmosférické testy jaderných zbraní, prováděné od roku 1945. Po dohodě USA, Velké Británie a SSSR byly zastaveny v roce 1963. Podle UNSCEAR [2] se uskutečnilo celkem 540 atmosférických testů s celkovým výtěžkem 440 Mt. Úhrnné množství radionuklidů připadající na globální spad se odhaduje na 622 PBq ${ }^{90} \mathrm{Sr}$ a 948 PBq ${ }^{137} \mathrm{Cs}\left(\mathrm{PBq}=10^{15} \mathrm{~Bq}\right)$ [2]. Podrobnější údaje o depozici vybraných radionuklidů k roku 1990 uvádějí Van der Stricht a Kirchmann [3].

\section{Vertical Distribution of Radioactive Caesium-137 in Soil}

\section{EVA JURANOVÁ, JOSEF KRATINA, BARBORA SEDLÁŘOVÁ, DIANA MAREŠOVÁ, MICHAL NOVÁK, IRENA POHLOVÁ, JOSEF VOJTĚCH DATEL}

Keywords: radioactivity - caesium-137 - soil - contamination vertical distribution - ground water vulnerability

\section{ABSTRACT}

In the past, the environment of the Czech Republic was contaminated with anthropogenic radionuclides as a result of atmospheric nuclear weapon testing and the Chernobyl accident. The paper summarises results of vertical migration of ${ }^{137} \mathrm{Cs}$ in soil in selected sites, performed as part of collecting data for ground water vulnerability assessment. Three sites with a different land cover were included (forest, meadow and arable land). In order to determine vertical migration of anthropogenic radionuclides, soil samples were collected up to the depth of $100 \mathrm{~cm}$ and subsequently analysed using the gamma-ray spectrometry. Furthermore, certain soil properties (soil texture, humus content) were determined. The results show that ${ }^{137} \mathrm{Cs}$ radionuclide contamination is still measurable in soil. The highest ${ }^{137} \mathrm{Cs}$ activity in the three sites ranged between $21.0 \mathrm{~Bq} \cdot \mathrm{kg}^{-1}$ and $32.2 \mathrm{~Bq} \cdot \mathrm{kg}^{-1}$. These maximum values were detected in the top soil layer (up to $10 \mathrm{~cm}$ ). Hence, ${ }^{137} \mathrm{C}$ s has a very slow migration rate and is mostly strongly bound in soil. However, a minor part of ${ }^{137} \mathrm{Cs}$ can be transported deeper over time. The depth where ${ }^{137} \mathrm{Cs}$ measurable activity was reached was estimated at $30 \mathrm{~cm}$ or $35 \mathrm{~cm}$ in two sites. The depth in the third site was even $80 \mathrm{~cm}$. There are potential other impacts that could affect the transport of ${ }^{137} \mathrm{Cs}$. In terms of ground water vulnerability, it seems that ground water is fairly well protected from ${ }^{137} \mathrm{Cs}$ penetration. This finding shall be verified by ground water analysis and evaluation of further data in the next project phase.

\section{INTRODUCTION}

Anthropogenic radionuclides arise as a result of human activities and with a few exceptions do not naturally occur in the environment. However, they may be introduced there by human activity [1]. Atmospheric nuclear weapon testing that started to be performed in 1945 had the greatest impact on the contamination of the Northern hemisphere by anthropogenic radionuclides. Following a treaty between the USA, UK and USSR, the tests were halted in 1963. According to UNSCEAR [2], a total of 540 atmospheric tests were performed with an overall output of $440 \mathrm{Mt}$. The total amount of radionuclides attributable to the global fallout is estimated at $622 \mathrm{PBq}{ }^{90} \mathrm{Sr}$ and $948 \mathrm{PBq}{ }^{137} \mathrm{Cs}\left(\mathrm{PBq}=10^{15}\right.$ $\mathrm{Bq}$ ) [2]. More detailed data about the deposition of selected radionuclides as of 1990 are provided by Van der Stricht and Kirchmann [3] 
Nejvýznamnější událostí z hlediska radioaktivní kontaminace území České republiky je havárie jaderné elektrárny v Černobylu na dnešní Ukrajině. K havárii došlo 26. dubna 1986 a úniky radionuklidů pokračovaly až do května 1986 [3-5]. Emise radionuklidů při černobylské havárii se projevila významnou kontaminací i na území České republiky [6]. Atlas [7] uvádí pro Českou republiku celkovou průměrnou plošnou depozici ${ }^{137} \mathrm{Cs}$ včetně kontaminace po atmosférických testech jaderných zbraní 7,6 kBq· $\mathrm{m}^{-2}$, jen z černobylské havárie pak 4,3 kBq· $\mathrm{m}^{-2}$ (zpráva [8] uvádí střední hodnotu 4,2 kBq· $\mathrm{m}^{-2}$ ). Černobylská plošná kontaminace byla diferencována podle lokální meteorologické situace a determinována zejména výskytem srážek v inkriminovaném období. Prímá data o plošné depozici ${ }^{137}$ Cs na území České republiky Ize nalézt ve zprávě [8].

$\checkmark$ současnosti jsou některé $z$ těchto radionuklidů, zejména ${ }^{137} \mathrm{Cs}$ a prípadně ${ }^{90} \mathrm{~S} r$, stále prítomny v prostředí, a to nejen v okolí černobylské elektrárny [1, 9-11], ale i v oblastech vzdálenějších [12-16]. Bylo pozorováno, že od doby vniknutí těchto radionuklidů do životního prostředí jejich množství průběžně klesá, a to $v$ důsledku jejich radioaktivní přeměny i různých migračních jevů. V České republice jsou v současnosti hodnoty velmi nízké, ale měřitelné [5, 13, 17-21].

Z uvedeného je zřejmé, že reziduální znečištění po atmosférických testech jaderných zbraní a po havárii jaderného reaktoru v Černobylu na českém území přetrvává. Účelem této práce bylo zjistit současnou míru kontaminace půdního nadloží podzemních zvodní a hloubku, které tato kontaminace do současnosti ve vertikálním půdním profilu dosáhla, a to zejména kvůli dalšímu vyhodnocení zranitelnosti podzemních vod.

\section{METODIKA}

Vertikální distribuce umělých radionuklidů v půdě je sledována v několika lokalitách, které byly na základě širšího kontextu vybrány pro další vyhodnocení zranitelnosti podzemních vod. V tomto článku jsou prezentovány výsledky ze tři lokalit (Hatín, Krašlovice a Veltruby), přičemž každá reprezentuje rozdílný typ krajinného pokryvu (Corine Land Cover). U lokality Hatín šlo o jehličnatý les, u Krašlovic o louku a u Veltrub dle databáze Corine Land Cover o ornou půdu. Podle dostupných dat se typ krajinného pokryvu v těchto lokalitách v období po havárii v Černobylu nezměnil [22-26]. Vybrané lokality jsou zobrazeny na mapce na obr. 1 .

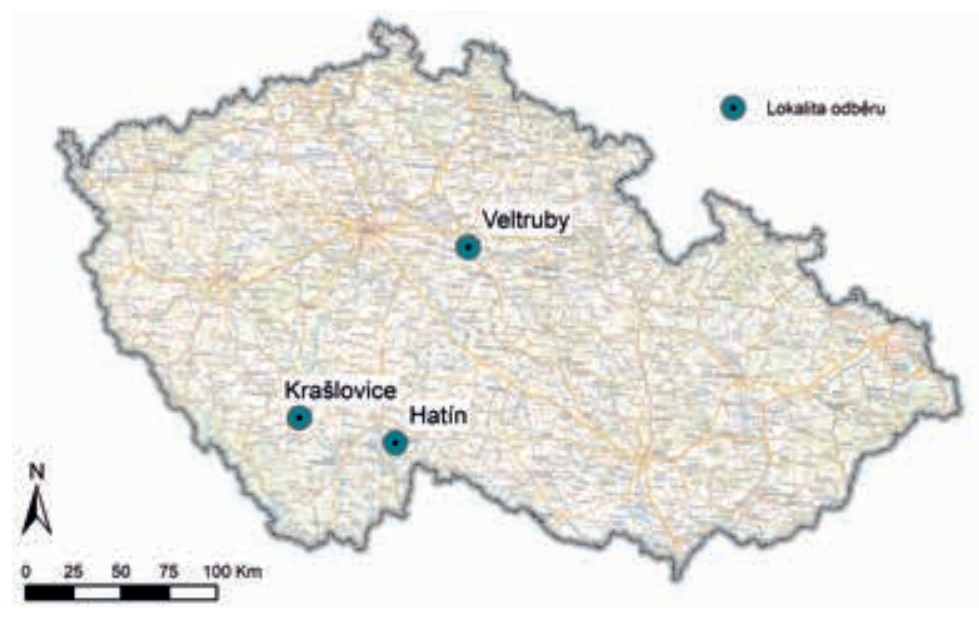

Obr. 1. Umístění lokalit odběru vzorkư pưd

Samotný odběr vzorků probíhal na dané lokalitě za pomoci půdní sondy spojením 17 dílčích vzorků odebraných ve vytyčené oblasti (čtverec $5 \times 5$ m). Hloubka odběru byla $100 \mathrm{~cm}$, jednotlivé vzorky byly odebírány ve vrstvách o tlouštice $5 \mathrm{~cm}$ v horních $50 \mathrm{~cm}$ půdního profilu, níže potom ve vrstvách po
The Chernobyl accident in today's Ukraine was an event that caused the most significant radioactive contamination of the Czech Republic. The accident occurred on 26/4/1986 and radionuclide leaks continued until May 1986 [3-5]. The emission of radionuclides during the Chernobyl accident significantly contaminated the territory of the Czech Republic [6]. The Atlas [7] quotes total average spatial deposition of ${ }^{137} \mathrm{Cs}$ in the Czech Republic including contamination following the atmospheric nuclear weapon testing of $7.6 \mathrm{kBq} \cdot \mathrm{m}^{-2}$, deposition caused by the Chernobyl accident itself being $4.3 \mathrm{kBq} \cdot \mathrm{m}^{-2}$ (the Report [8] states a mean value of $4.2 \mathrm{kBq} \cdot \mathrm{m}^{-2}$ ). Chernobyl spatial contamination was differentiated according to the local meteorological situation, especially the occurrence of precipitation in the concerned period. Direct data about spatial deposition of ${ }^{137} \mathrm{Cs}$ in the Czech Republic may be found in the Report [8].

At present, some of these radionuclides, in particular ${ }^{137} \mathrm{Cs}$ and possibly also ${ }^{90} \mathrm{Sr}$, are still present in the environment not only in the vicinity of the Chernobyl power plant [1, 9-11] but also in more remote areas [12-16]. It has been observed that since the introduction of these radionuclides into the environment their amount has been gradually on the decline as a result of radioactive transformation of the monitored radionuclides and various migration phenomena. Radionuclide values in the Czech Republic are currently very low but still measurable $[5,13,17-21]$.

It is clear from the above that residual contamination following atmospheric nuclear weapon testing and the Chernobyl nuclear reactor accident still remains in the Czech territory. The purpose of this paper has been to establish the current degree of contamination of the soil superstratum of underground aquifers and the depth that this contamination has reached in the vertical soil profile to date, primarily in order to be able to further evaluate ground water vulnerability.

\section{METHODOLOGY}

Vertical distribution of anthropogenic radionuclides in soil has been monitored in several sites, selected with a view to a broader context for further evaluation of ground water vulnerability. This paper presents results from three sites (Hatín, Krašlovice and Veltruby), each of which represents a different Corine Land Cover. In the Hatín site it was a coniferous forest, in Krašlovice a meadow and in Veltruby arable land. According to available data, the type of land cover in these sites has not changed since the Chernobyl accident [22-26]. Fig. 1 shows the selected sites on a map.

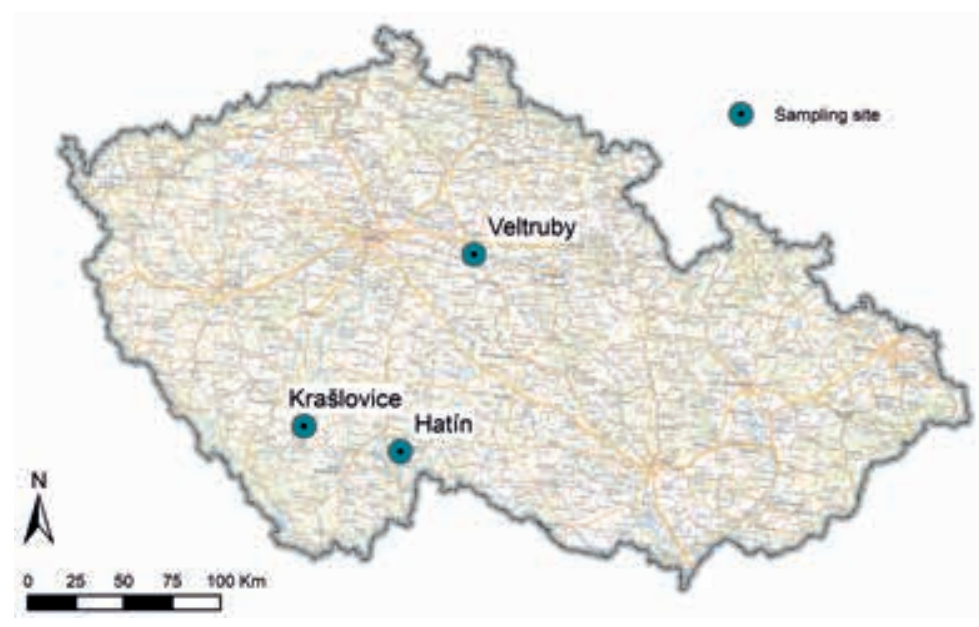

Fig. 1. Location of the soil sampling sites 
$10 \mathrm{~cm}$, jak je schematicky zobrazeno na obr. 2. Po odběru byly vzorky bez prodlení dopraveny do laboratoře, kde byly vysušeny, homogenizovány a poté připraveny pro stanovení radionuklidů.

Odběry vzorků i následné analýzy byly provedeny pracovníky Zkušební laboratoře technologií a složek životního prostředí VúV TGM, která je držitelem osvědčení o akreditaci Českého institutu pro akreditaci (ČIA) a osvědčení o správné činnosti laboratoře Střediska pro posuzování laboratoří ASLAB.

Pro stanovení umělých radionuklidů byla v laboratoři využita metoda spektrometrie záření gama. Analýza probíhala na zařizení firmy Canberra Packard s koaxiálním polovodičovým detektorem typu HPGe dle ČSN EN ISO 10703 (757630) [27] upravené pro pevné vzorky. Geometrie měření byla ověřována pomocí ethalonů Českého metrologického institutu. Podmínky měření (hmotnost vzorku, doba měření) byly voleny tak, že hodnota nejmenší detekovatelné aktivity (NDA) pro ${ }^{137} \mathrm{Cs}$ na hladině významnosti $a=\beta=0,05$ byla $1,3 \mathrm{~Bq} \cdot \mathrm{kg}^{-1}$ nebo nižší; výsledky vyjádřeny v Bq·kg ${ }^{-1}$ sušiny vzorku. Ze spektra záření gama byly vyhodnocovány umělé radionuklidy: ${ }^{57} \mathrm{Co},{ }^{60} \mathrm{Co},{ }^{134} \mathrm{Cs},{ }^{137} \mathrm{Cs}$ a ${ }^{241} \mathrm{Am}$, do dalšího hodnocení však byla zahrnuta jen data ${ }^{137} \mathrm{Cs}$, protože ostatní zmíněné radionuklidy nebyly ve vzorcích detekovány. Hodnoty NDA pro tyto radionuklidy byly nižší než: 0,9 Bq. $\mathrm{kg}^{-1}\left({ }^{57} \mathrm{Co}\right), 1,7 \mathrm{~Bq} \cdot \mathrm{kg}^{-1}{ }^{\left({ }^{60} \mathrm{Co}\right)}, 1,8 \mathrm{~Bq} \cdot \mathrm{kg}^{-1}\left({ }^{134} \mathrm{Cs}\right)$ a $4,0 \mathrm{~Bq} \cdot \mathrm{kg}^{-1}$ $\left.{ }^{(241} \mathrm{Am}\right)$.

Dále byly $\vee$ půdních vzorcích laboratorně stanoveny obsahy zrnitostních frakcí (jíl, prach a písek) v souladu s normou ČSN EN ISO 17892-4 [28] a výsledky vyhodnoceny dle USDA [29]. Nakonec bylo stanoveno množství oxidovatelného uhlíku (C $C_{o x}$ ) dle normy ISO 14235:1998 [30]. C ox byl prepočítán na obsah humusu pomocí Welteho koeficientu. a)

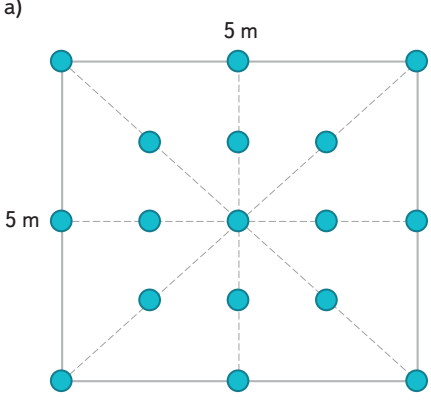

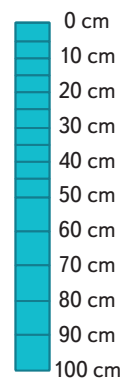

c)

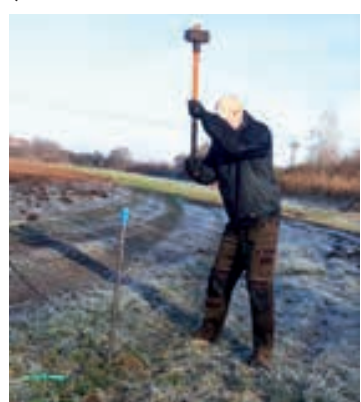

Obr. 2. Odběr vzorků vertikálního profilu půdy: a) schéma odběru dílčích vzorků ve čtverci $5 \times 5$ m, b) znázornění odběru jednotlivých vzorků dle hloubky odběru, c) práce $v$ terénu s odběrovým zařízením - půdní sondou

\section{VÝSLEDKY A DISKUZE}

Radionuklid ${ }^{137} \mathrm{Cs}$ byl detekován ve vzorcích půdy ve všech třech hodnocených lokalitách. Podrobné výsledky stanovení ${ }^{137} \mathrm{C}$ s ve vertikálním profilu půdy v jednotlivých lokalitách jsou zobrazeny na obr. 3-5. Je vidět, že nejvyšší aktivita ${ }^{137} \mathrm{Cs}$ $\left(a_{\max }{ }^{137} \mathrm{C} s\right)$ byla zjištěna ve vrstvách nejblíže $k$ povrchu. $V$ lokalitách Krašlovice a Veltruby to bylo v horních $10 \mathrm{~cm}$ půdy, kde ve vrstvách $0-5 \mathrm{~cm}$ a $5-10 \mathrm{~cm}$ byly naměřené hodnoty ${ }^{137} \mathrm{Cs}$ podobné, v lokalitě Hatín to bylo jen $v$ horních $5 \mathrm{~cm}$, poté se již aktivita významně snižovala. To svědčí o pevné vazbě většiny ${ }^{137} \mathrm{Cs}$ v půdě a velmi pomalém transportu vertikálním profilem, nebot' od poslední významné depoziční události uplynulo v době odběrů vzorků přibližně 35 let. To potvrzují i další studie, které se tématem zabývaly, např. [15, 31]. Zjištěné výsledky odpovídají i predchozí práci VúV TGM [32], kde bylo sledováno ${ }^{137} \mathrm{Cs}$ ve vertikálním profilu půdy v roce 1995 a 2015.

Maximální aktivity ${ }^{137} \mathrm{Cs}$ v jednotlivých lokalitách byly srovnatelné (viz tab. 1), stejně jako průměrné aktivity ${ }^{137} \mathrm{Cs}$ ve sledované vrstvě pưdy, vypočítané jako aritmetický průměr naměřených hodnot vyšších než $1,3 \mathrm{~Bq} \cdot \mathrm{kg}^{-1} \vee$ jednotlivých
The actual sampling in the given sites took place with the help of a soil probe by putting together 17 partial samples collected in the marked-out area (a square of $5 \times 5 \mathrm{~m}$ ). The sampling depth was $100 \mathrm{~cm}$ and individual samples were taken in $5-\mathrm{cm}$ thick layers in the upper $50 \mathrm{~cm}$ of the soil profile and further down in 10-cm thick layers, as shown by Fig. 2. Following the collection, the samples were immediately transported to a lab where they were dried, homogenised and prepared for the determination of radionuclides.

The sampling and the subsequent analyses were performed by staff of the Testing Laboratory of Technologies and Environment Components of the TGM WRI, which holds an accreditation granted by the Czech Accreditation Institute $(C \mid A)$ and a good laboratory practice certificate granted by the Centre for the assessment of laboratories ASLAB.

The gamma-ray spectrometry method was used to determine anthropogenic radionuclides in the lab; the analysis was carried out pursuant to the ČSN EN ISO 10703 (757630) technical standard [27] adjusted for solid samples, using Canberra Packard equipment with a coaxial semi-conductor detector of the HPGe type. The measurement geometry was verified by the Czech Metrology Institute standards. Measurement conditions (sample weight, measurement duration) were selected in such a way that the Minimum Detectable Activity (MDA) of ${ }^{137} \mathrm{Cs}$ in the confidence interval $a=\beta=0.05$ was $1.3 \mathrm{~Bq} \cdot \mathrm{kg}^{-1}$ or lower. The results were expressed in Bq. $\mathrm{kg}^{-1}$ of the dry matter of the sample. The following anthropogenic radionuclides were determined from the gamma radiation spectre: ${ }^{57} \mathrm{Co},{ }^{60} \mathrm{Co},{ }^{134} \mathrm{Cs},{ }^{137} \mathrm{Cs}$ and ${ }^{241} \mathrm{Am}$. However, only data concerning ${ }^{137} \mathrm{Cs}$ were included in further evaluation because the remaining radionuclides were not detected in the samples. The MDA of these radionuclides was lower than $\left.0.9 \mathrm{~Bq} \cdot \mathrm{kg}^{-1}\left({ }^{57} \mathrm{Co}\right), 1.7 \mathrm{~Bq} \cdot \mathrm{kg}^{-1}{ }^{(60} \mathrm{Co}\right), 1.8 \mathrm{~Bq} \cdot \mathrm{kg}^{-1}{ }^{\left({ }^{134} \mathrm{Cs}\right)}$ and $4.0 \mathrm{~Bq} \cdot \mathrm{kg}^{-1}\left({ }^{241} \mathrm{Am}\right)$.

Besides, soil texture (sand, silt, clay) of the samples was determined in the lab in accordance with the ČSN EN ISO 17892-4 technical standard [28] and the results were evaluated according to the USDA [29]. Besides, the amount of oxidisable carbon $\left(C_{o x}\right)$ was determined in accordance with the ISO 14235:1998 standard [30]. $C_{\text {ox }}$ was converted to humus content using Welte's coefficient.

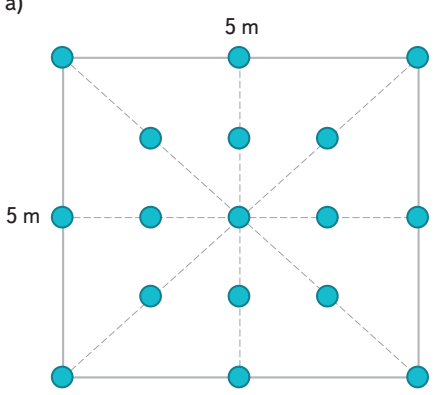

b)

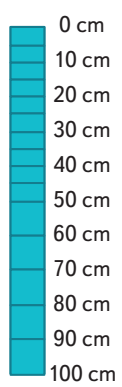

c)

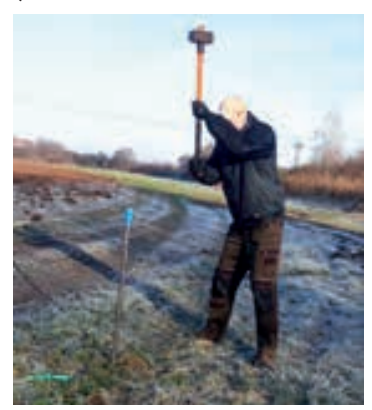

Fig. 2. Soil vertical profile sampling: a) Chart showing the collection of partial samples in a $5 \times 5$ m square; b) Illustration of sampling according to the depth; c) Use of sampling equipment (a soil probe) in the field

\section{RESULTS AND DISCUSSION}

Radionuclide ${ }^{137} \mathrm{Cs}$ was detected in soil samples in all the three evaluated sites. Fig. 3 to 5 show detailed results of the determination of ${ }^{137} \mathrm{Cs}$ in the vertical soil profile in the individual sites. The highest activity of ${ }^{137} \mathrm{Cs}\left(\mathrm{a}_{\max }\left({ }^{137} \mathrm{Cs}\right)\right)$ was established in layers closest to the surface. In Krašlovice and Veltruby it was in the upper $10 \mathrm{~cm}$ of soil and the measured values of ${ }^{137} \mathrm{Cs}$ were similar in $0-5 \mathrm{~cm}$ and 5-10 cm, whereas in the Hatín site it was only in the upper $5 \mathrm{~cm}$ and then the activity significantly decreased. This is evidence of the fact that most of ${ }^{137} \mathrm{Cs}$ is strongly bound in soil and is transported through its vertical profile only very slowly because at the time of the sampling approximately 35 years had 
vrstvách do hloubky 100 cm, vážený na základě tlouštky odebírané vrstvy. To odpovídá i dostupným údajům [7] o depozici ${ }^{137}$ Cs po havárii v Černobylu $\checkmark$ daných lokalitách, nebot všechny tři lokality se nacházely ve stejném rozmez odhadované depozice ${ }^{137} \mathrm{Cs}$ po černobylské havárii (4-10 kBq· $\mathrm{m}^{-2}$ ), podobně jako dle [8]. Vybrané lokality tedy odpovídají spíše průměrnému zasažení černobylským spadem (podle [8] byla střední hodnota spadu po černobylské havári $\checkmark$ České republice $4,2 \mathrm{kBq} \cdot \mathrm{m}^{-2}$, maximální naměřená hodnota byla $80 \mathrm{kBq} \cdot \mathrm{m}^{-2}$ ). Aktuálně naměřené aktivity ${ }^{137} \mathrm{Cs}$ souhlasí i s výsledky dřivější studie provedené ve VúV TGM [32].

Z hlediska hodnocení vertikálního transportu ${ }^{137} \mathrm{Cs}$ a posouzení zranitelnosti podzemních vod je důležité, do jaké hloubky kontaminace ${ }^{137} \mathrm{Cs} v$ půdním profilu pronikla. Z tohoto důvodu byla vyhodnocena hloubka, v níž byla zjištěna aktivita ${ }^{137} \mathrm{Cs}$ větší než $1,3 \mathrm{~Bq} \cdot \mathrm{kg}^{-1}$. Lze konstatovat, že v lokalitách Krašlovice a Hatín byla hloubka proniknutí ${ }^{137} \mathrm{Cs}$ podobná - aktivity ${ }^{1{ }^{137} \mathrm{C}}$ s vyšší než $1,3 \mathrm{~Bq} \cdot \mathrm{kg}$ byly nalezeny do hloubky $30 \mathrm{~cm}$, resp. $35 \mathrm{~cm}$. Výrazně vyšší hloubka byla zjištěna v lokalitě Veltruby, a to $80 \mathrm{~cm}$. Vzhledem k tomu, že v lokalitě Veltruby jde o typ krajinného pokryvu orná půda, přichází v úvahu rozptyl kontaminace ve vertikálním profilu v důsledku orby. Z literatury [31] je zřejmé, že vertikální distribuce ${ }^{137} \mathrm{Cs} v$ obdělávaných půdách se značně liší od neobdělávaných. Tam, kde probíhala kultivace půdy orbou, Ize očekávat, že v horní vrstvě půdy bude aktivita ${ }^{137} \mathrm{Cs}$ distribuována rovnoměrně $v$ důsledku mechanického promíchávání. I v této lokalitě je však většina kontaminace soustředěna do povrchové vrstvy půdy (horních $10 \mathrm{~cm}$ ) a poté klesá, z čehož lze usuzovat, že k tomuto způsobu hospodaření na daném pozemku nedocházelo ( $v$ době odběru byla lokalita pokryta travním porostem). Toto zjištění proto odporuje klasifikaci lokality Veltruby podle Corine Land Cover jako orné půdy. Zvláštnosti v tomto profilu vykazuje i doplňková půdní analýza, jak je uvedeno níže.

Dle specializované pưdní mapy [33] byl půdní typ ve všech třech prípadech určen jako fluvizem, tedy půda vyvinutá $v$ nivách vodních toků z povodňových sedimentů, kde dochází k občasnému zaplavení a zvýšení vlhkosti půdy. To bylo rovněž lokálně potvrzeno pomocí půdní sondy. V prípadě lokalit Krašlovice a Hatín jde o fluvizem modální, na odběrovém místě Veltruby se nachází fluvizem glejová. $V$ prrípadě fluvizemě glejové v lokalitě Veltruby jsou př́tomny reduktomorfní znaky $\vee$ hloubce od $60 \mathrm{~cm}$, které značí pravidelné nasycování profilu vodou. Trvalá hladina podzemní vody však v hloubce odběru nebyla zjištěna ani v jednom z profilů. Půdní druh (USDA) byl v případě lokality Hatín určen jako hlinitý písek (obsah písku přes 80 \%), v Krašlovicích jako písčitá hlína (obsah písku přes $50 \%$ ) a ve Veltrubech jako hlína prachovitá (obsah prachu přes $50 \%$ ). Zrnitostní složení půd ve sledovaných lokalitách je uvedeno na obr. 6.

Obsah humusu v půdě lokality Hatín byl velmi vysoký ve svrchních horizontech $(22,6 \%$ humusu $v$ hloubce $0-5 \mathrm{~cm})$, s hloubkou odběru rovnoměrně klesal až na 0,77 \% humusu v hloubce $90-100 \mathrm{~cm}$. Naměřené hodnoty ${ }^{137} \mathrm{Cs}$ ve svrchní vrstvě lesní půdy v lokalitě Hatín přibližně odpovídají hodnotám zjištěným v lesním humusu ve studii [34] (s príhlédnutím k podílu humusu v analyzované půdě). Rovnoměrný pokles obsahu humusu byl zaznamenán také v případě lokality Krašlovice, kde byl však obsah humusu výrazně nižší než v lokalitě Hatín, přesto v případě svrchních horizontů vysoký $(5,43 \%$ v hloubce $0-5 \mathrm{~cm}$, 0,28 \% v hloubce 90-100 cm). Klesající obsah humusu s hloubkou půdy je standardní jev, proto byly překvapivé výsledky rozboru půdy v lokalitě Veltruby, kde byl obsah humusu v hloubce 0-5 cm velmi vysoký (9,43\%) a dle očekávání s hloubkou klesal, ale od 50-60 cm začal opět stoupat a v hloubkách od 80 do 100 cm byl vyšší než 12 \%. Jelikož se lokalita nachází v rovině, dá se vyloučit, že by tento jev byl způsoben erozí a transportem materiálu. Jako pravděpodobnější vysvětlení se jeví technický zásah do půdního profilu, případně vliv zaplavování a s tím související vertikálně proměnný obsah humusu ve vrstvě povodňových hlín. Tyto možné události mohly také ovlivnit distribuci ${ }^{137} \mathrm{Cs}$. Pro vysvětlení bude potřeba dalšího průzkumu této lokality. Změny v obsahu humusu ve vertikálních profilech sledovaných lokalit je možno vidět na obr. 6. passed since the last major deposition event. This is confirmed also by other papers dedicated to this topic, e.g. [15, 31]. The established results correspond with work previously carried out by the TGM WRI [32] that monitored ${ }^{137} \mathrm{Cs}$ in the vertical soil profile in 1995 and in 2015.

Maximum activity of ${ }^{137} \mathrm{Cs}$ in the individual sites was comparable (see Tab. 1) and so was average activity of ${ }^{137} \mathrm{Cs}$ in the monitored soil layer calculated as arithmetic average of measured values higher than $1.3 \mathrm{~Bq} \cdot \mathrm{kg}^{-1}$ in the individual layers up to the depth of $100 \mathrm{~cm}$, weighed on the basis of sampled layer thickness. This corresponds with available data [7] regarding the deposition of ${ }^{137} \mathrm{Cs}$ in the individual sites after the Chernobyl accident where all the three sites were in the same range of estimated deposition of ${ }^{137} \mathrm{Cs}$ after the Chernobyl accident (4-10 kBq. $\mathrm{m}^{-2}$ ); likewise according to [8]. The selected sites therefore match rather average Chernobyl fallout (according to [8], the mean fallout value after the Chernobyl accident stood at $4.2 \mathrm{kBq} \cdot \mathrm{m}^{-2}$ in the Czech Republic whilst the maximum measured value stood at $80 \mathrm{kBq} \cdot \mathrm{m}^{-2}$ ). The currently measured activity of ${ }^{137} \mathrm{Cs}$ corresponds with results of an earlier study carried out by the TGM WRI [32].

As regards the evaluation of vertical transport of ${ }^{137} \mathrm{Cs}$ and assessment of ground water vulnerability, it is important what depth ${ }^{137} \mathrm{Cs}$ contamination has reached in the soil profile. For the above reason, the depth with established ${ }^{137} \mathrm{Cs}$ activity exceeding $1.3 \mathrm{~Bq} \cdot \mathrm{kg}^{-1}$ was evaluated. It may be stated that in the Krašlovice and Hatín sites the depth of ${ }^{137} \mathrm{Cs}$ penetration was similar: ${ }^{137} \mathrm{Cs}$ activity exceeding $1.3 \mathrm{~Bq} \cdot \mathrm{kg}^{-1}$ was established up to the depth of 30 or $35 \mathrm{~cm}$. A significantly greater depth was established in the Veltruby site, namely $80 \mathrm{~cm}$. Since the land cover in the Veltruby site comprises arable land, contamination may have been dispersed in the vertical profile as a result of tillage. It is clear from the bibliography [31] that vertical distribution of ${ }^{137} \mathrm{Cs}$ in cultivated soil considerably differs from that in uncultivated soil. Where soil was cultivated by tillage, the upper soil layer is expected to have evenly distributed ${ }^{137} \mathrm{Cs}$ activity due to mechanical mixing. However, since even in this site most of the contamination is concentrated in the top soil layer (the upper $10 \mathrm{~cm}$ ) and then it drops, it may be presumed that this type of cultivation of the given plot of land did not take place (at the time of the sampling the site was covered by grass). This finding goes against the classification of the site according to the Corine Land Cover as arable land. Supplementary soil analysis also shows peculiarities of this profile, as stated below.

According to a specialised Soil Map [33], the soil type in all the three cases was determined as fluvial soil, which was locally confirmed by a soil probe. In the Krašlovice and Hatín sites there is modal fluvial soil whereas in the Veltruby sampling site there is gley fluvial soil. Fluvial soil develops in fluvial valleys from flood sediments and is occasionally flooded as a result of which soil humidity increases. Gley fluvial soil in the Veltruby site contains reductomorphic signs at the depth of $60 \mathrm{~cm}$, which is evidence of regular profile saturation with water. However, permanent ground water level was not established in the sampling depth of any of the profiles. Soil type (USDA) in the Hatín site was determined as clay sand (sand content exceeding $80 \%$ ), in Krašlovice as sand clay (sand content exceeding $50 \%$ ) and in Veltruby as silt clay (silt content exceeding $50 \%$ ). The composition of soil texture in the monitored sites is shown by Fig. 6 .

Humus content in soil in the Hatín site was very high in the upper horizons ( $22.6 \%$ of humus in the depth of $0-5 \mathrm{~cm}$ ); as the sampling depth increased, it evenly dropped to $0.77 \%$ of humus in the depth of $90-100 \mathrm{~cm}$. The measured values of ${ }^{137} \mathrm{Cs}$ in the upper forest soil layer in the Hatín site roughly correspond to values established in forest humus in the paper [34] (with a view to humus content in the analysed soil). An even drop in humus content was noted also in the Krašlovice site where humus content was, however, significantly lower than in Hatín, yet it was high in the upper horizons ( $5.43 \%$ at the depth of $0-5 \mathrm{~cm}$ and $0.28 \%$ at the depth of $90-100 \mathrm{~cm}$ ). Declining humus content linked to increasing soil depth is a standard phenomenon and that is why soil analysis results in the Veltruby site were interesting because humus content there was 


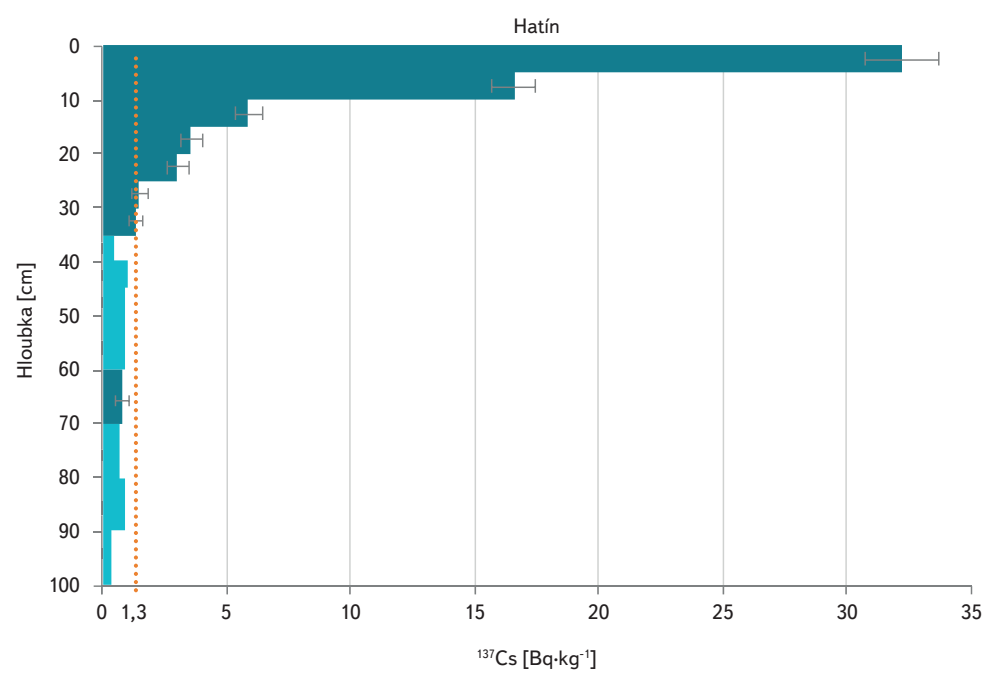

Obr. 3. Aktivita ${ }^{137} \mathrm{Cs}$ naměřená ve vertikálním profilu půdy v lokalitě Hatín (světlejší barvou jsou znázorněny hodnoty NDA tam, kde naměřené hodnoty ležely pod NDA)

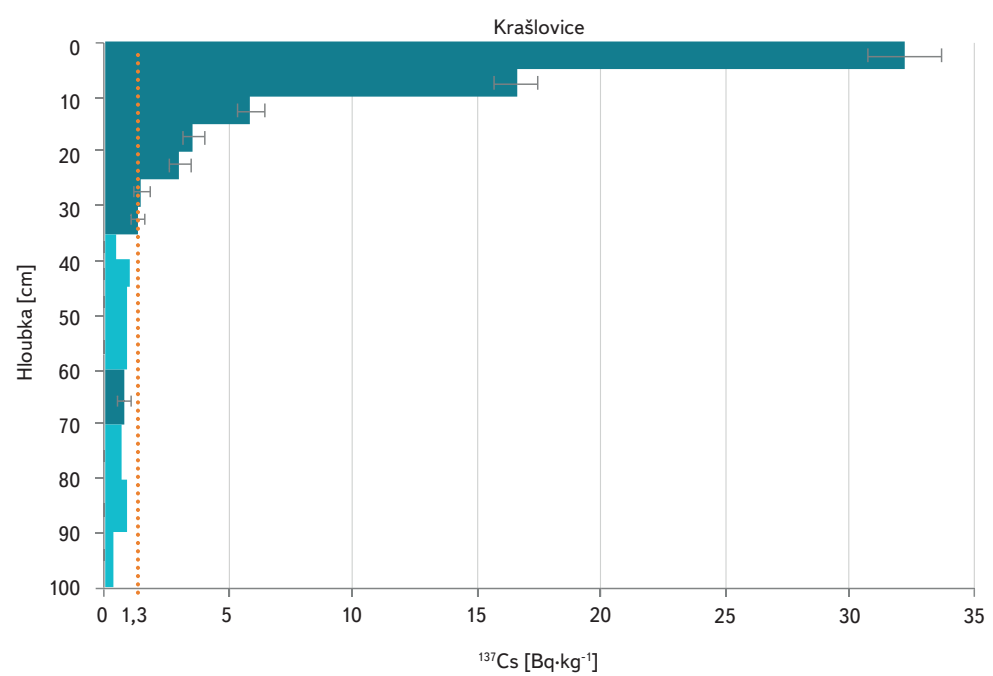

Obr. 4. Aktivita ${ }^{137} \mathrm{Cs}$ naměřená ve vertikálním profilu půdy v lokalitě Krašlovice (světlejší barvou jsou znázorněny hodnoty NDA tam, kde naměřené hodnoty ležely pod NDA)

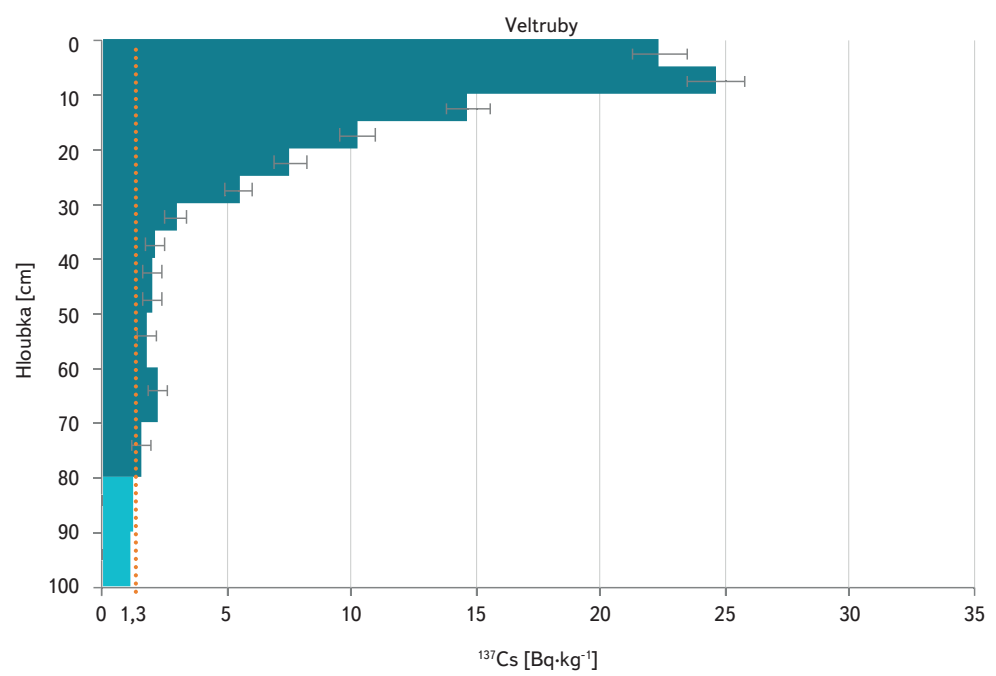

Obr. 5. Aktivita ${ }^{137} \mathrm{C}$ s naměřená ve vertikálním profilu půdy v lokalitě Veltruby (světlejší barvou jsou znázorněny hodnoty NDA tam, kde naměřené hodnoty ležely pod NDA)

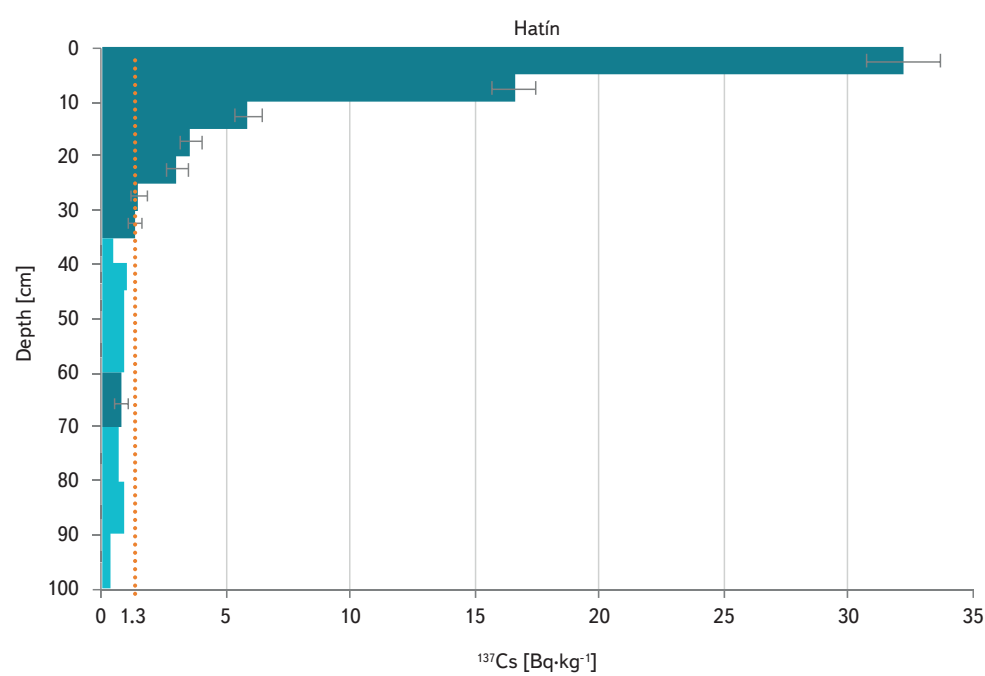

Fig. $3 .{ }^{137} \mathrm{C}$ activity measured in the vertical soil profile in the Hatín site (the light blue colour stands for measured values below the MDA)

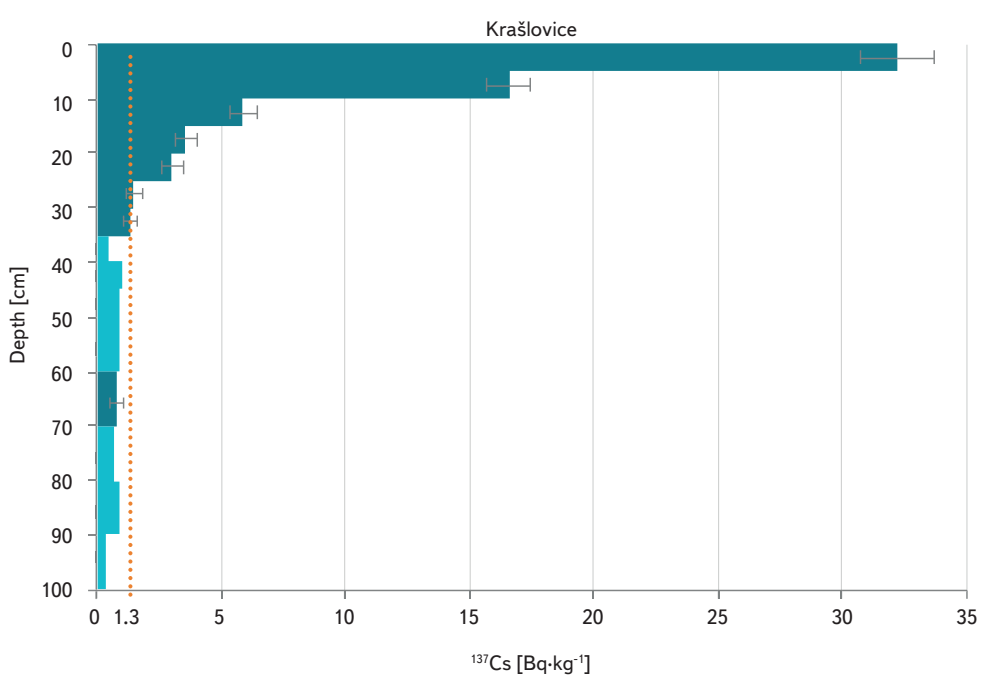

Fig. $4 .{ }^{137} \mathrm{Cs}$ activity measured in the vertical soil profile in the Krašlovice site (the light blue colour stands for measured values below the MDA)

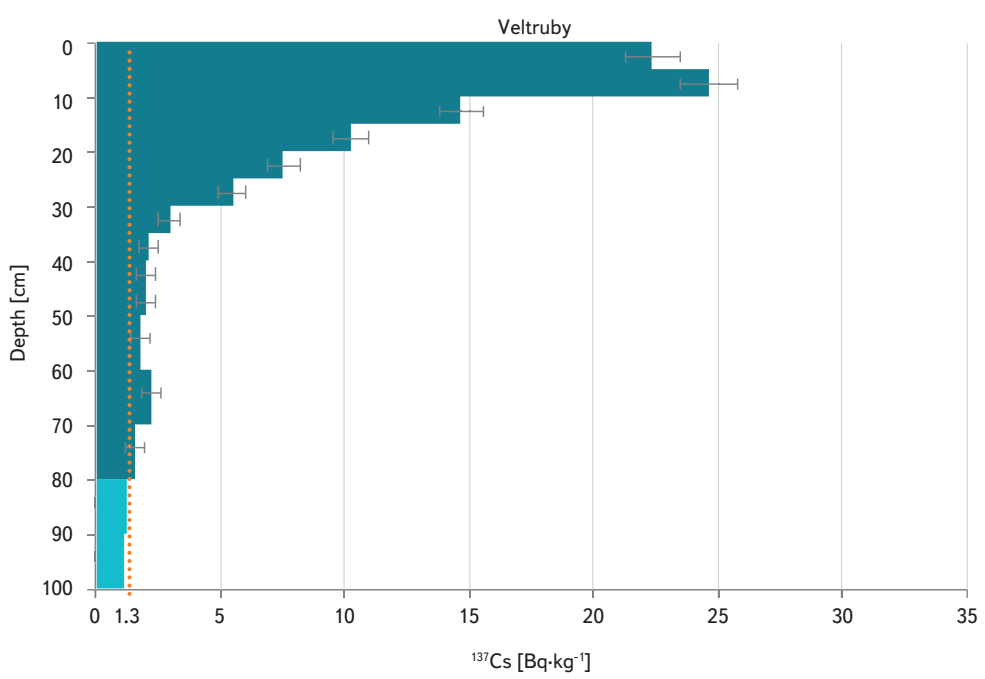

Fig. ${ }^{1{ }^{137} \mathrm{C}}$ s activity measured in the vertical profile in the Veltruby site (the light blue colour stands for measured values below the MDA) 
Tab. 1. Přehled výsledků vyhodnoceni stanoveni a ktivity ${ }^{137} \mathrm{C}$ s ve vertikálním profilu půdy ve sledovaných lokalitách: $a_{\max }{ }^{\left({ }^{37} \mathrm{Cs}\right)}-$ nejvyšši aktivita ${ }^{137} \mathrm{Cs}$ naměřená ve vertikálním

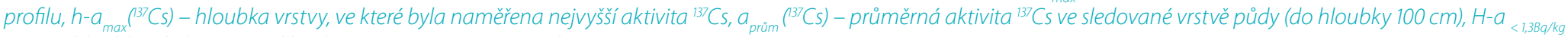
${ }^{\left({ }^{37} \mathrm{CS}\right)}$ - hloubka, do které pronikla aktivita ${ }^{137} \mathrm{CS}$ vyšš́i než 1,3 Bq. $\mathrm{kg}^{-1}$.

\begin{tabular}{|c|c|c|c|c|c|c|}
\hline Lokalita & Datum odběru & $\begin{array}{l}\mathrm{a}_{\max }\left({ }^{137} \mathrm{Cs}\right) \\
{\left[\mathrm{Bq} \cdot \mathbf{k g}^{-1}\right]}\end{array}$ & $\begin{array}{l}\mathrm{h}-\mathrm{a}_{\max }\left({ }^{137} \mathrm{Cs}\right) \\
{[\mathrm{cm}]}\end{array}$ & $\begin{array}{l}a_{\text {prům }}\left({ }^{137} \mathrm{Cs}\right) \\
{\left[\mathrm{Bq} \cdot \mathrm{kg}^{-1}\right]}\end{array}$ & $\begin{array}{l}\mathrm{H}-\mathrm{a}_{<1,3 \mathrm{~Bq} / \mathrm{kg}}\left({ }^{137} \mathrm{Cs}\right) \\
{[\mathrm{cm}]}\end{array}$ & $\begin{array}{l}\text { Krajinný } \\
\text { pokryv }\end{array}$ \\
\hline Hatín & 10. 5. 2021 & $32,2 \pm 1,5$ & $0-5$ & 4,4 & 35 & Jehličnatý les \\
\hline Krašlovice & 23. 7. 2020 & $\begin{array}{l}21,0 \pm 0,9 \\
20,7 \pm 1,1\end{array}$ & $\begin{array}{l}0-5 \\
5-10\end{array}$ & 5,1 & 30 & Pastvina, louka \\
\hline Veltruby & 24. 11. 2020 & $\begin{array}{l}22,4 \pm 1,1 \\
24,6 \pm 1,2\end{array}$ & $\begin{array}{l}0-5 \\
5-10\end{array}$ & 7,0 & 80 & Orná půda \\
\hline
\end{tabular}

Tab. 1. Summary evaluation of ${ }^{137} \mathrm{Cs}$ activity in the vertical soil profile in the monitored sites: $a_{\max }{ }^{\left({ }^{37} \mathrm{CS}\right)}$ - maximum activity of ${ }^{137} \mathrm{Cs}$ measured in the vertical profile; $h$ - $a_{\text {max }}\left({ }^{137} \mathrm{CS}\right)-$ depth of the layer where the maximum ${ }^{137} \mathrm{Cs}$ activity was measured; $\mathrm{a}_{\text {aver }}\left({ }^{137} \mathrm{CS}\right)$ - average ${ }^{137} \mathrm{Cs}$ activity in the monitored soil layer (up to the depth of $\left.100 \mathrm{~cm}\right) ; \mathrm{H}$ - $\mathrm{a}_{<1.38 \mathrm{G} / \mathrm{kg}}\left({ }^{137} \mathrm{CS}\right)-$ depth into which ${ }^{137} \mathrm{Cs}$ contamination higher than $1.3 \mathrm{~Bq} \cdot \mathrm{kg}^{-1}$ penetrated

\begin{tabular}{|c|c|c|c|c|c|c|}
\hline Site & Sampling date & $\begin{array}{l}\mathrm{a}_{\max }\left({ }^{137} \mathrm{Cs}\right) \\
{\left[\mathrm{Bq} \cdot \mathbf{k g}^{-1}\right]}\end{array}$ & $\begin{array}{l}\mathrm{h}-\mathrm{a}_{\max }\left({ }^{137} \mathrm{Cs}\right) \\
{[\mathrm{cm}]}\end{array}$ & $\begin{array}{l}\mathrm{A}_{\text {aver }}\left({ }^{137} \mathrm{Cs}\right) \\
{\left[\mathrm{Bq} \cdot \mathrm{kg}^{-1}\right]}\end{array}$ & $\begin{array}{l}\mathrm{H}-\mathrm{a}_{<1.3 \mathrm{~Bq} / \mathrm{kg}}\left({ }^{137} \mathrm{Cs}\right) \\
{[\mathrm{cm}]}\end{array}$ & Land cover \\
\hline Hatín & $10 / 5 / 2021$ & $32.2 \pm 1.5$ & $0-5$ & 4.4 & 35 & Coniferous forest \\
\hline Krašlovice & $23 / 7 / 2020$ & $\begin{array}{l}21.0 \pm 0.9 \\
20.7 \pm 1.1\end{array}$ & $\begin{array}{l}0-5 \\
5-10\end{array}$ & 5.1 & 30 & Pasture, meadow \\
\hline Veltruby & 24/11/2020 & $\begin{array}{l}22.4 \pm 1.1 \\
24.6 \pm 1.2\end{array}$ & $\begin{array}{l}0-5 \\
5-10\end{array}$ & 7.0 & 80 & Arable land \\
\hline
\end{tabular}
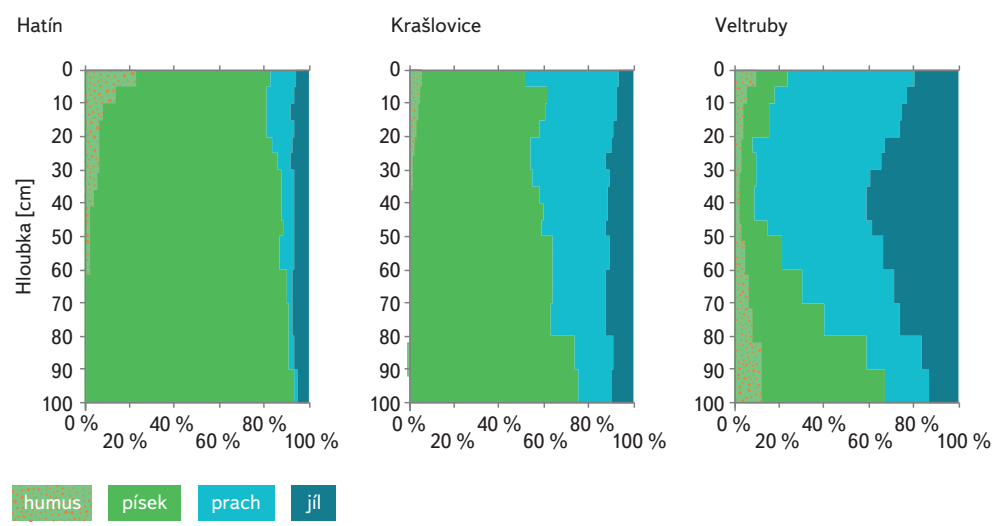

Obr. 6. Vlastnosti půd ve vertikálním profilu ve sledovaných lokalitách - zrnitostní složení (písek, prach, jíl) a podíl humusu

\section{ZÁVĚR}

Výsledky sledování vertikální distribuce ${ }^{137} \mathrm{Cs}$ v půdě potvrdily, že kontaminace pưdy tímto umělým radionuklidem je v České republice stále měřitelná, přestože od poslední významné depoziční události (havárie v Černobylu) uplynulo již 35 let. Většina aktivity ${ }^{137} \mathrm{C}$ j je v půdě pevně vázána, takže rychlost jeho transportu do hlubších vrstev půdního profilu je jen velmi pomalá a většina zjištěné aktivity ${ }^{137} \mathrm{Cs}$ se nachází v povrchové vrstvě půdy. Přesto v závislosti na místních vlastnostech půdy a dalších podmínkách dochází k postupnému pronikání kontaminace do větší hloubky, jde však o výrazně nižší aktivity, než jsou zjištovány při povrchu.
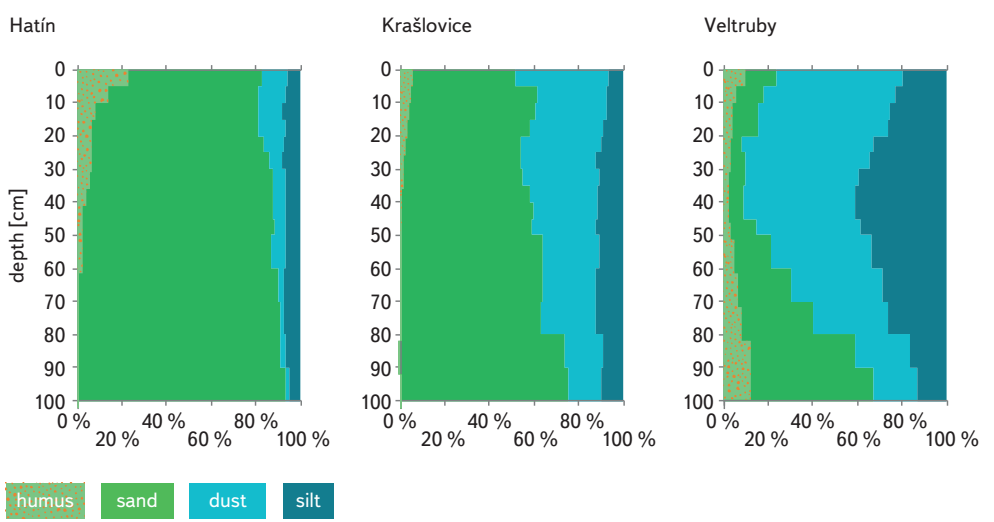

Fig. 6. Soil properties in the vertical profile in the monitored sites - soil texture (sand, silt, clay) and humus content

very high (9.43\%) at the depth of $0-5 \mathrm{~cm}$ and decreased in greater depths but then started to rise again in the depths of 80 to $100 \mathrm{~cm}$ and was higher than $12 \%$. Since the site is located in a flat area, it may be ruled out that this phenomenon would be caused by erosion and transport of material. A technical intervention into the soil profile or the impact of flooding and connected vertically changeable humus content in the flood soil layer seems to be a more plausible explanation. These possible events may also have had an impact on the distribution of ${ }^{137} \mathrm{Cs}$ in this site. In order to explain this, a further survey of this site shall be necessary. Fig. 6 shows changes in humus content in vertical profiles of the assessed sites. 
S ohledem na hodnocení zranitelnosti podzemních vod (jejich kontaminace ${ }^{137} \mathrm{C}$ ) Ize konstatovat, že většina ${ }^{137} \mathrm{C}$ je ve sledovaných lokalitách zachycena vrchní vrstvou půdy a $v$ úvahu přichází průnik jen velmi malého množstvi ${ }^{137} \mathrm{Cs}$. V následující fázi bude práce zaměřena na vyhodnocení půd v dalších lokalitách, dále na zjištění velmi nízkých objemových aktivit ${ }^{137} \mathrm{Cs}$, jež by mohly do podzemních vod proniknout, a také na vyhodnocení transportu ${ }^{90} \mathrm{Sr}$, které obecně vykazuje větší mobilitu v pưdních systémech [35-36].

\section{Poděkování}

Tento článek byl prippraven v rámci projektu "Inovativní metody detekce ultranizkých koncentrací radionuklidů k hodnocenízranitelnosti zdrojů pitné vody pri jaderné havárii", č. VI20192022142, financovaného Ministerstvem vnitra ČR v rámci Bezpečnostního výzkumu České republiky 2015-2022.

\section{Literatura}

[1] IZRAEL, Y. A. Chernobyl Radionuclide Distribution and Migration. Health Physics [on-line]. 2007, 93(5), s. 410-417. ISSN 0017-9078. Dostupné Z: doi: 10.1097/01.HP.0000285092.10598.41

[2] United Nations Scientific Committee on the Effects of Atomic Radiation (UNSCEAR). Sources and Effects of lonizing Radiation. Volume I: Sources [on-line]. Report to the General Assembly, with Scientific Annexes. New York: United Nations Scientific Committee on the Effects of Atomic Radiation (UNSCEAR), 2000. Dostupné z: https://www.unscear.org/docs/publications/2000/ UNSCEAR_2000_Report_Vol.I.pdf

[3] VAN DER STRICHT, E., KIRCHMANN, R. Radioecology: Radioactivity and Ecosystems. Liège (Belgium): Fortemps, 2001. 624 s. ISBN 2-9600316-0-1.

[4] United Nations Scientific Committee on the Effects of Atomic Radiation (UNSCEAR). Sources and Effects of lonizing Radiation. Volume ll: Effects [on-line]. Report to the General Assembly, with Scientific Annexes. New York: United Nations Scientific Committee on the Effects of Atomic Radiation (UNSCEAR), 2000. Dostupné z: https://www.unscear.org/docs/publications/2000/UNSCEAR_2000_ Report_Vol.II.pdf

[5] SMITH, J., BERESFORD, N. A. Chernobyl — Catastrophe and Consequences. 1. vyd. Berlin, Heidelberg: Springer, 2005. 310 s. Springer Praxis Books. ISBN 978-3-540-23866-9.

[6] HANSLÍK, E., MAREŠOVÁ, D., JURANOVÁ, E. Vliv atmosférických testů jaderných zbraní a významných jaderných havárií na obsah radioaktivních látek v povrchových vodách na území České republiky. Sdružení oboru vodovodũ a kanalizací ČR (SOVAK). 2013, 22(10), s. 12-15. ISSN 1210-3039.

[7] DE CORT, M., DUBOIS, G., FRIDMAN, Sh. D., GERMENCHUK, M. G., IZRAEL, Y. A., JANSSENS, A., JONES, A. R., KELLY, G. N., KVASNIKOVA, E. V., MATVEENKO, I. I., NAZAROV, I. M., POKUMEIKO, Y. U., SITAK, V. A., STUKIN, E. D., TABACHNY, L. Y., TSATUROV, Y. S., AVDYUSHIN, S. I. Atlas of Caesium Deposition on Europe after the Chernobyl Accident [on-line]. B. m.: Office for Official Publications of the European Communities. 1998 [vid. 18. srpen 2021]. ISBN 92-828-3140-X. Dostupné z: http://op.europa.eu/en/ publication-detail/-/publication/110b15f7-4df8-49a0-856f-be8f681ae9fd

[8] RULÍK, P., HELEBRANT, J. Mapa kontaminace pưdy České republiky ${ }^{137}$ CS po havárii JE Černobyl. [on-line]. Zpráva SúRO, č. 22/2011 [vid. 19. srpen 2021]. Zprávy k černobylské havárii jaderné elektrány $v$ roce 1996. Dostupné z: https://www.suro.cz/cz/publikace/cernobyl/ plosna-aktivita-radionuklidu-zjistena-ve-vzorcich-odebranych-pud

[9] BONDAR, Yu., NENASHEV, R., KALINICHENKO, S., MARCHENKO, Yu., DOWDALL, M., STANDRING, W., BROWN J PETTERSEN, M SKIPPERUD L Z ZABROTSKI, V The Distribution of ${ }^{137} \mathrm{CS},{ }^{90} \mathrm{Sr}$, and ${ }^{241} \mathrm{Am}$ in Waterbodies of Different Origins in the Belarusian Part of Chernobyl Exclusion Zone. Water Air and Soil Pollution [on-line]. 2015, 226, s. 63. Dostupné z: doi: 10.1007/s11270-015-2354-1

[10] KASHPAROV, V., LEVCHUK, S., ZHURBA, M., PROTSAK, V., KHOMUTININ, Y., BERESFORD, N. A., CHAPLOW, J. S. Spatial Datasets of Radionuclide Contamination in the Ukrainian Chernobyl Exclusion Zone. Earth System Science Data [on-line]. 2018, 10(1), s. 339-353. ISSN 1866-3508. Dostupné z: doi: 10.5194/essd-10-339-2018

[11] IVANOV, Y. A., LEWYCKYJ, N., LEVCHUK, S. E., PRISTER, B. S., FIRSAKOVA, S. K., ARKHIPOV, N. P., ARKHIPOV, A. N., KRUGLOV, S. V., ALEXAKHIN, R. M., SANDALLS, J., ASKBRANT, S. Migration of Cs-137 and Sr-90 from Chernobyl Fallout in Ukrainian, Belarussian and Russian Soils. Journal of Enviromental Radioactivity [on-line]. 1997, 35(1), s.1-21. ISSN 0265-931X. Dostupné z: doi:10.1016/S0265-931X(96)00036-7

[12] SANGIORGI, M., CEBALLOS, M. A. H., IURLARO, G., CINELLI, G., DE CORT, M. 30 Years of European Commission Radioactivity Environmental Monitoring Data Bank (REMdb) - An Open Door to Boost Environmental Radioactivity Research. Earth System Science Data [on-line]. 2019, 11(2), s. 589-601. ISSN 1866-3508. Dostupné z: doi: 10.5194/essd-11-589-2019

[13] PRÖHL, G., EHLKEN, S., FIEDLER, I., KIRCHNER, G., KLEMT, E., ZIBOLD, G. Ecological Half-lives of ${ }^{90} \mathrm{Sr}$ and ${ }^{{ }^{137} \mathrm{CS}}$ in Terrestrial and Aquatic Ecosystems. Journal of Environmental Radioactivity [on-line]. 2006, 91(1), s. 41-72. ISSN 0265-931X. Dostupné z: doi: 10.1016/j.jenvrad.2006.08.004

\section{CONCLUSION}

The results of monitoring vertical distribution of ${ }^{137} \mathrm{Cs}$ in soil confirmed that soil contamination with this anthropogenic radionuclide in the Czech Republic is still measurable even though already 35 years have passed since the last major deposition event (the Chernobyl accident). Most of ${ }^{137} \mathrm{Cs}$ activity is strongly bound in soil and the speed of its transport into deeper soil profile layers is therefore only very slow and most of established ${ }^{137} \mathrm{Cs}$ activity is thus located in the top soil layer. In spite of that, contamination gradually penetrates into greater depths depending on local soil properties and other conditions; however, this activity is significantly lower than activity established at the surface.

As regards the evaluation of ground water vulnerability (its contamination with ${ }^{137} \mathrm{Cs}$ ), it may be said that most of ${ }^{137} \mathrm{Cs}$ is captured by the top soil layer in the monitored sites and only a small amount of ${ }^{137} \mathrm{Cs}$ may penetrate further. Further work shall focus on evaluating soil in other sites and on determining very low volume activities of ${ }^{137} \mathrm{Cs}$ that could get to ground water as well as on evaluating the transport of ${ }^{90} \mathrm{Sr}$, which generally shows higher mobility in soil systems $[35,36]$.

\section{Acknowledgements}

This paper was written within project No. VI20192022142 entitled "Innovative Methods of Detecting Ultra-low Radionuclide Concentrations for the Purposes of Evaluating the Vulnerability of Drinking Water Sources during a Nuclear Accident" funded by the Ministry of the Interior of the CR within the framework of the Security Research Programme of the Czech Republic 2015-2022. 
[14] CHIBOWSKI, S., MITURA, A. Studies of the Rate of Migration of Radiocesium in Some Types of Soils of Eastern Poland. Science of the Total Environment [on-line]. 1995, 170(3), s. 193-198. ISSN 0048-9697. Dostupné z: doi: 10.1016/0048-9697(95)04707-3

[15] ALMGREN, S., ISAKSSON, M. Vertical Migration Studies of Cs-137 from Nuclear Weapons Fallout and the Chernobyl Accident. Journal of Enviromental Radioactivity [on-line]. 2006, 91(1-2), s. 90-102 ISSN 0265-931X. Dostupné z: doi: 10.1016/j.jenvrad.2006.08.008

[16] RUHM, W., KAMMERER, L., HIERSCHE, L., WIRTH, E. Migration of Cs-137 and Cs-134 in Different Forest Soil Layers. Journal of Environmental Radioactivity [on-line]. 1996, 33(1), s. 63-75. ISSN 0265-931X. Dostupné z: doi: 10.1016/0265-931X(95)00069-M

[17] HANSLÍK, E., MAREŠOVÁ, D., JURANOVÁ, E., SEDLÁŘOVÁ, B. Kinetics of H-3, Sr-90 and Cs-137 Conten Changes in Hydrosphere in the VItava River System (Czech Republic). Journal of Environmenta Radioactivity [on-line]. 2018, 188, s. 1-10. ISSN 0265-931X. Dostupné z: doi: 10.1016/j.jenvrad.2017.11.029

[18] JURANOVÁ, E., HANSLÍK, E., MAREŠOVÁ, D. Temporal Development of Radiocaesium and Radiostrontium Concentrations in the Hydrosphere-Methods of Evaluation Water Air and Soil Pollution [on-line]. 2015, 226(10). ISSN 0049-6979. Dostupné z: doi: 10.1007/s11270-015-2601-5

[19] MAREŠOVÁ, D., JURANOVÁ, E., SEDLÁŘOVÁ, B. Vliv Jaderné elektrárny Temelín na obsah vybraných radionuklidů $v$ povrchových vodách. Vodohospodárské technicko-ekonomické informace. 2020, 62(4), s. 38-43. ISSN 0322-8916, 1805-6555.

[20] HANSLÍK, E., MAREŠOVÁ, D., JURANOVÁ, E., SEDLÁŘOVÁ, B. Změny obsahu radionuklidů v povrchové vodě v okolí Jaderné elektrárny Temelín v období 1990-2016. Vodohospodárskétechnickoekonomické informace. 2017, 59(6), s. 18-23. ISSN 0322-8916, 1805-6555.

[21] Environmental Consequences of the Chernobyl Accident and their Remediation: Twenty Years of Experience [on-line]. Report of the Chernobyl Forum Expert Group 'Environment'Text. STI/PUB/1239. Vienna: International Atomic Energy Agency (IAEA), 2006. Radiological Assessment Reports Series No. 8. Dostupné z: https://www-pub.iaea.org/MTCD/Publications/PDF/Pub1239_web.pdf

[22] European Enviroment Agency (EEA) under the Framework of the Copernicus Programme. Corine Land Cover (CLC) 1990, Version 20202041 [on-line]. 2019 [vid. 19. srpen 2021]. Dostupné z: http://land. copernicus.eu/pan-european/corine-land-cover/clc-1990/view

[23] European Enviroment Agency (EEA) under the Framework of the Copernicus Programme. Corine Land Cover (CLC) 2000, Version 2020_20u1 [on-line]. 2019 [vid. 19. srpen 2021]. Dostupné z: https://land. copernicus.eu/pan-european/corine-land-cover/clc-2000/view

[24] European Enviroment Agency (EEA) under the Framework of the Copernicus Programme. Corine Land Cover (CLC) 2006, Version 202020 1 [on-line]. 2019 [vid. 9. srpen 2021]. Dostupné z: https://land. copernicus.eu/pan-european/corine-land-cover/clc-2006/view

[25] European Enviroment Agency (EEA) under the Framework of the Copernicus Programme. Corine Land Cover (CLC) 2012, Version 2020_20u1 [on-line]. 2019 [vid. 9. srpen 2021]. Dostupné z: https://land. copernicus.eu/pan-european/corine-land-cover/clc-2012/view

[26] European Enviroment Agency (EEA) under the Framework of the Copernicus Programme. Corine Land Cover (CLC) 2018, Version 2020_20u1 [on-line]. 2019 [vid. 9. srpen 2021]. Dostupné z: https://land. copernicus.eu/pan-european/corine-land-cover/clc2018/view

[27] ČSN EN ISO 10703:2008/Z1 (757630) Kvalita vod - Stanovení objemové aktivity radionuklidů - Metoda spektrometrie zárení gama s vysokým rozlišením. B. m.: Úřad pro technickou normalizaci, metrologi a státní zkušebnictví (ÚNMZ), 2016

[28] ČSN EN ISO 17892-4 (72 1007) Geotechnický prüzkum a zkoušení - Laboratorni zkoušky zemin - Část 4 Stanovenízrnitosti. B. m.: Český normalizační institut (ČNI), 2017

[29] USDA Textural Soil Classification. Study Guide. Module 3. B. m.: United States Department of Agriculture, Soil Conservation Service, 1987. Soil Mechanics Level I.

[30] $15014235: 1998$ Soil quality - Determination of Organic Carbon by Sulfochromic Oxidation. B. m. International Organization for Standardization (ISO), 1998

[31] JAGERCIKOVA, M., CORNU, S., LE BAS, Ch., EVRARD, O. Vertical Distributions of Cs-137 in Soils: a Meta-Analysis. Journal of Soils and Sediments [on-line]. 2015, 15(1), s. 81-95. Dostupné z: doi: 10.1007/ s11368-014-0982-5

[32] JURANOVÁ, E., HANSLÍK, E., SEDLÁŘOVÁ, B. Vertikální migrace umělých radionuklidů v půdním profilu. In: SEDLÁŘOVÁ, B. ed. XXIV. Konzultační dny pro pracovníky vodohospodářských radiologických laboratoři. Lednice: VÚV TGM, 2016. ISBN 978- 80-87402-56-6.

[33] Česká geologická služba (ČGS). Pưdní mapa 1: 50000 [on-line]. [vid. 27. srpen 2021]. Dostupné z: https://mapy.geology.cz/pudy/

[34] PILÁTOVÁ, H., SUCHARA, I., RULÍK, P., SUCHAROVÁ, J., HELEBRANT, J., HOLÁ, M. Mapy obsahu ${ }^{137} \mathrm{CS}$ v humusu lesního ekosystému České republiky v roce 2005 [on-line]. Zpráva SúRO č. 26/2011. Dostupné z: https://www.suro.cz/cz/rms/monitorovani-slozek-zivotniho-prostredi/ mapy-obsahu-cs137-v-humusu-v-2005

[35] BUGAI, D., SMITH, J., HOQUE, M. A. Solid-Liquid Distribution Coefficients (Kd-s) of Geological Deposits at the Chernobyl Nuclear Power Plant Site with Respect to Sr, Cs and Pu Radionuclides: A Short Review. Chemosphere [on-line]. 2020, 242, s. 125-175. ISSN 0045-6535. Dostupné z: doi: 10.1016/j. chemosphere.2019.125175

[36] Handbook of Parameter Values for the Prediction of Radionuclide Transfer in Terrestrial and Freshwater Environments [on-line]. Text. 472. Vienna: International Atomic Energy Agency (IAEA) 2010 [vid. 20. srpen 2021]. Technical Reports Series. Dostupné z: https://www-pub.iaea.org/mtcd/ publications/pdf/trs472 web.pdf

\section{Autoři}

\author{
Ing. Eva Juranová \\ 凶eva.juranova@vuv.cz \\ ORCID: 0000-0001-9021-7307
}

Ing. Josef Kratina, Ph.D.

凶josef.kratina@vuv.cz

ORCID: 0000-0001-6095-586X

Ing. Barbora Sedlářová

凶barbora.sedlarova@vuv.cz

ORCID: 0000-0003-0271-8473

RNDr. Diana Marešová, Ph.D.

凶diana.maresova@vuv.cz

ORCID: 0000-0001-9047-6747

\section{Michal Novák}

凶michal.novak@vuv.cz

\section{Ing. Irena Pohlová}

凶irena.pohlova@vuv.cz

ORCID: 0000-0003-0758-6465

RNDr. Josef Vojtěch Datel, Ph.D.

凶josef.datel@vuv.cz

ORCID: 0000-0003-1451-0135

Výzkumný ústav vodohospodářský T. G. Masaryka, Praha

Přispěvek prošel lektorským řízením.

DOI: 10.46555/VTEI.2021.09.003 